\title{
A bridge between worlds: understanding network structure to understand change strategy
}

\author{
Alan J. Daly · Kara S. Finnigan
}

Published online: 30 January 2009

(C) The Author(s) 2009. This article is published with open access at Springerlink.com

\begin{abstract}
A number of scholars are exploring district and site relations in organizational change efforts in the larger policy context of No Child Left Behind. These studies suggest the importance of the central office as a support to the work of reform and offer strategies for building relations between district offices and sites in order to implement and sustain change efforts. What is frequently overlooked in these studies is that organizational change efforts are often socially constructed. Therefore, examining the underlying social networks may provide insight into structures that support or constrain efforts at change. This exploratory case study uses social network analysis and interviews to examine the communication and knowledge network structures of central office and site leaders in an 'in need of improvement' district facing sanctions under No Child Left Behind. Findings indicate sparse ties among and between school site and central office administrators, as well as a centralized network structure that may constrain the exchange of complex information and ultimately inhibit efforts at change.
\end{abstract}

Keywords District-site relations - Educational change $\cdot$ Leadership ·

Educational reform $\cdot$ Social capital $\cdot$ Social network analysis $\cdot$ Network structure

\section{Introduction}

Efforts at changing public educational systems in support of better achievement for students are commonplace across the globe. Many countries have experienced or are experiencing prime ministers, premiers, or presidents that define themselves as the

We are indebted to the anonymous reviewers for their insightful and instructive comments on the development of this manuscript.

A. J. Daly (凶)

Education Studies, University of California, San Diego, USA

e-mail: ajdaly@ucsd.edu

K. S. Finnigan

University of Rochester, Rochester, NY, USA 
'education' leader and as such enact a series of reforms targeted at improving their nation's schools (Levin 2007). Typically, the subsequent gap between policy intentions and implementation, however, impedes these large-scale change efforts (Berman and McLaughlin 1978; Datnow et al. 2006; Fielding 2001; Hubbard et al. 2006; McLaughlin 1990; Spillane 2000).

This gap between intention and implementation is certainly the case in the United States under the No Child Left Behind (NCLB) Act of 2001. NCLB enacted a series of large-scale reforms targeted primarily at eliminating the persistent achievement gap by 2014. This legislation is built on several major assumptions. The first assumption is that schools can achieve unprecedented levels of equitable achievement among all subgroups of students in a short period of time without substantially changing current funding structures. Second, there are known methods of reform that will accomplish the task. Third, a formal structure of testing, threat of sanctions, and loss of both fiscal and human resources are the strongest incentives to produce improvement (Orfield et al. 2004). Ironically, under NCLB the students who have been traditionally 'left behind', and for whom presumably the law was enacted, are now attending schools that disproportionately suffer the effects of sanctions and loss of resources (Sunderman et al. 2005).

The 'teeth' of the law are embedded in the accountability provisions that mandate Adequate Yearly Progress (AYP) toward established benchmarks. Failure to meet these targets results in a district or school being designated as 'in need of improvement' (INI) and a series of progressive sanctions that ultimately lead to a district or school being restructured. Perhaps most important, the number of districts and schools in INI is growing. During the 2004-2005 school year, individual states identified more than 9,000 schools as INI, representing a nearly $50 \%$ increase over the previous year (Stullich et al. 2006). In California, the most populous state in the U.S., 2,218 schools were designated INI during the 2006-2007 school year, representing nearly 1/3 of all the schools in the state receiving federal funding. Exacerbating the issue, many schools designated as INI continue to remain in this status rather than move off accountability sanctions. For example, while $57 \%$ of the 90 Michigan schools in the final, more drastic stage of restructuring during 2005-2006 moved out of INI status the following year (Center on Education Policy 2007), only 5\% of the 700 schools facing this sanction in California during 2006-2007 improved enough to be removed from INI status (Center on Education Policy 2008).

Given the pressure to achieve at increasingly high levels or risk facing progressive sanctions, educators have ratcheted up the number of change efforts underway in districts and schools to exit INI status (Mintrop 2004; Mintrop and Trujillo 2005). It is at this juncture of sanction, urgency for change, and generally failed efforts at improvement that we examine the leadership network of the Dos Mundos School District, ${ }^{1}$ an urban fringe district in the third year of INI. We have undertaken this case study to explore the underlying social networks of communication and knowledge transfer that are in place between district central office and school site administrators to examine whether these underlying networks influence the determination and direction of change (Tsai 2002). Through our examination of the social networks in Dos Mundos we seek to understand the relationship between these networks and the capacity for districts to change when facing accountability sanctions.

Past research suggests that organizational improvement is closely linked to the ties within and across units (McGrath and Krackhardt 2003; Tenkasi and Chesmore 2003). In the field of education, this has led to the development of professional learning communities

${ }^{1}$ All names are pseudonyms. 
and emphasis on collaborative structures (McLaughlin and Talbert 1993; Newmann and Wehlage 1995). Most often, these types of communities are developed to increase communication and collaboration between teachers within schools; however, the literature from outside of education suggests that these ties, whether formal or informal, may be necessary throughout an entire district rather than isolated within schools to generate district-wide improvement. Recent research has found that informal social structures, in particular, provide opportunities for communication, information sharing, transfer and development of new knowledge between individuals, levels, and units within an organization (Ahuja 2000; Tsai and Ghoshal 1998). To date, there is little understanding of the underlying networks within low-performing districts or between district and school leaders. A more in-depth investigation of the networks within districts 'in need of improvement' may uncover important characteristics of these networks that may facilitate or impede efforts at change. Therefore, our study is guided by the following research questions:

1. What is the underlying social network structure of Dos Mundos and what does this structure suggest in terms of supporting or constraining efforts at change?

2. How do site and district leaders perceive their leadership network and its effect on the flow of communication and knowledge throughout the district?

3. To what extent does position within the formal and informal network structure affect leaders' perceptions of the flow of communication and knowledge, and the district's capacity for change?

To better understand how the underlying network of interactions within an organization may affect efforts at change, we drew upon social network theory and methods. Social network analysis (SNA) is a systemic approach used to quantify and visualize the ties and overall structure of formal and informal networks. Given the increasing number of districts and schools in improvement status in the U.S. there is an urgency to better understand the complexities of these organizations and provide strategies to educators working within these organizations. Understanding the structure of social networks may assist leaders to be better able to meet organizational goals once they understand the frequency and interaction patterns of communication and knowledge transfer between individuals and groups (Ahuja 2000; Tsai and Ghoshal 1998). A systematic examination of underlying networks provides a lens through which to view organizations' capacity for change.

We begin by briefly outlining the importance of a strong relationship between district and site leaders in enacting change as theoretical support for examining the bounded network of central office and site leaders. We then provide a review on social network theory and analysis and discuss how this body of research may be a useful lens to understand how networks may facilitate or inhibit change. Lastly, we discuss our study methodology, findings, and implications.

\section{Importance of district-school relations}

In an effort to understand the context in which contemporary schools operate, a numbers of scholars have shifted their focus from the school site as the unit of reform to exploring the important relationship between central offices and sites in engendering change (Datnow and Castellano 2003; Elmore and Burney 1997; Harris and Chrispeels 2006; Hightower et al. 2002; Honig 2004; Hubbard et al. 2006; Marsh 2002; McLaughlin and Talbert 2003; Togneri and Anderson 2003). This line of inquiry acknowledges that schools are embedded 
within a larger district context and that this context may have a direct impact on the success of change efforts.

While the district context is important to our study, schools and districts also operate within, and are influenced by, the larger state and national educational systems. Districts and the schools they serve reside in a nested system of state and federal policies and a range of 'non-system actors' (Coburn 2005). Educational policies are linked in formal and informal ways from the Federal government to the state to the community and ultimately to the district and schools (Datnow et al. 2006). These linkages can be conceptualized as bridges between aspects of policy domains and influence both the structure and focus of districts as staff respond to the various policy pressures. Linkages may be formal such as specific mandates (e.g., NCLB), structural as in funding formulas, or relational as in the way that individuals work, interact, and network (Lasky 2004). Although our study focuses on the relational linkages between district and site leaders, we consider the impact of formal and structural linkages of the greater policy system to understand our results.

Recent research identifies the key role that districts play in school improvement (Massell and Goertz 1999; Spillane 1996). One attribute of reforming districts is a systemwide approach to improvement (Marsh et al. 2005). District administrators are in the position to support systems whether they are moving toward goals or 'stuck' in dysfunctional patterns (Rosenholtz 1991). Datnow and Castellano (2003) further this idea arguing, "supportive conditions at the district level are important to successful implementation and sustainability of whole school reform (p. 203)." Targeted support is especially critical for low-performing schools in improving outcomes (Massell 2000; Massell and Goertz 1999). Beyond supportive conditions, scholars have also suggested that explicit, shared theories of action, mutual 'sense-making', and clear consistent communication around change efforts between central office administrators and site leaders results in greater systemic coherence and goal attainment (Agullard and Goughnour 2006). Finally, central office staff are strategically positioned to 'broker' resources, knowledge, and ideas across the district (Burch and Spillane 2004). These studies suggest the importance of a bridge between central office and site leaders for reform efforts to be successful. Absent that connection, successful efforts at reform appear remote (Leithwood et al. 2004).

Successful reform efforts, therefore, may require a shift in the way that change strategies are conceptualized and enacted within a school district. This shift entails a move from a singular focus on individualized segments of the organization to engaging the entire system in a network of connections. For example, a successful networked approach has been demonstrated in the United Kingdom through the National College of School Leadership's (NCSL) Network Learning Group of 104 schools (Earl and Katz 2007; Earl et al. 2006). This network yielded positive outcomes in a variety of areas including developing leadership, expanding boundaries, strengthening communities, and positively influencing student achievement (Earl et al. 2006). The key conditions of these successful networks included frequent and pervasive communication, shared understanding and purpose, joint challenging work, and relationships built on trust that enabled the transfer of tacit and explicit knowledge. Although the NCSL project represents a much broader network than may exist in a single school district, the implications from this work are consistent with the scholarship on district-site relations and potentially hold importance as a way to create and understand networks within school districts. Above all, the balance of this work suggests the need for a more interconnected systems approach to organizational change (Fullan 2005; Hargreaves and Fink 2006; McLaughlin and Talbert 2003), requiring that district and site leaders, “...think systemically about schools and their development 
and see educational organizations in terms of their interdependent parts" (Smylie et al. 2003, p. 155).

Studies of successful school districts that applied more systemic approaches to change suggest a range of specific strategies that schools and districts can take in building stronger intra-organizational ties (Chrispeels 2004; Honig 2004; Togneri and Anderson 2003). These strategies include creating structures for increased collaboration between central offices and sites (McLaughlin and Talbert 2003), enhancing communication channels (Agullard and Goughnour 2006), distributing leadership (Leithwood et al. 2007; Spillane 2006), and providing opportunities for input on decision-making (Brazer and Keller 2008). While, these strategies identify formal structures that may help build interorganizational ties, the broader literature on social networks suggests that in addition to these more formal structures district leaders should invest in the development of informal social relations.

From a network perspective, the work of an organization is captured well by Hubbard and colleagues (2006), who in their book on district reform define an organization as existing "in the interrelationships between activities of individuals" (p. 263). It is the interactions between and among individuals that comprise the culture and structure of an organization. The assumption that undergirds this definition is that changes in organizations are often socially constructed (Hubbard et al. 2006). Therefore, attempts to modify formal structures in support of greater collaboration, communication, shared leadership, and decision-making often require change in existing social relationships (Bartunek 2001; Borgatti and Foster 2003; Stevenson et al. 2003). It is the organizational interdependence of action (Giddens 1979), reflecting a network of ties, that may ultimately moderate, influence, and even determine the direction, speed, and depth of a planned change (Krackhardt 2001; Mohrman et al. 2003). According to Mohrman et al. (2003), because change processes emerge and are maintained through interpersonal relationships, “...lasting change does not result from plans, blueprints, and events. Rather change occurs through the interaction of participants (p. 321)." This research suggests that the careful exploration and analysis of the network of social relations in an organization may be an important first step in understanding and determining an appropriate change strategy, as well as identifying the potential for acceptance or resistance of individual members of the organization (Tenkasi and Chesmore 2003).

\section{Social network theory and analysis}

One of the basic conceptual foundations in understanding social network theory is the concept of social capital. A number of theorists have written on social capital; each foregrounding a different aspect of the concept and offering nuanced understanding of the idea (see, for example, Bourdieu 1986; Burt 1992; Coleman 1988; Lin 2001; Putnam 1993). Lin (2001) notes that the common denominator between all major theorists includes the understanding that social capital consists of, "The resources embedded in social relations and social structure which can be mobilized when an actor wishes to increase the likelihood of success in purposive action" (p. 24). Social capital is therefore an investment in the social relations in a system through which the resources of other individuals can be accessed, borrowed, or leveraged. This differentiates social capital from human capital, which refers to investments in training, development, or certifications of individuals, or physical capital that is contained in infrastructure and equipment (Bourdieu 1986; Coleman 1988; Dika and Singh 2002; Lin 2001). 
The idea of social capital has been increasingly used in education and has been connected to a variety of positive outcomes such as educational attainment (Dyk and Wilson 1999), educational aspirations as tied to institutional agents (Stanton-Salazar and Dornbusch (1995), and home-school connections (Horvat et al. 2003). However, while the effects of social capital are generally in the direction expected in terms of educational outcomes, researchers have suggested that additional empirical studies are necessary given the variation in both definition and outcome (Dika and Singh 2002). In response to this critique we have narrowed our focus and drawn heavily on the scholarship of network theorists who argue that much of social capital research must be strongly rooted in individual interactions and networks (Lin 1999; Portes 2000). Therefore, an understanding of the ties between individuals is foundational for our work.

Social capital can be operationalized as the resources embedded in social systems, accessed and used by actors for action (Lin 2001). Social capital is therefore concerned with the resources that exist in social relations (sometimes referred to as 'ties') between individuals as opposed to the resources of a specific individual. This implies that actors must be aware of the assets in their network and take action through social ties to access these resources (Portes and Sensenbrenner 1993). It is the quality of those ties between individuals in a social system that creates a structure that ultimately determines opportunities for social capital transactions and access to resources (Burt 1992; Coleman 1988, 1990; Granovetter 1973, 1982; Lin 2001; Putnam 1993, 1995). Strong social ties support the transfer of tacit, non-routine, or complex knowledge (Hansen 1999; Reagans and McEvily 2003; Uzzi 1997), joint problem solving (Uzzi 1997), and the development of coordinated solutions (Uzzi 1997). Strong ties also have been associated with low-conflict organizations (Nelson 1989). Less dense networks tend to be better suited for the transfer of simple, routine information (Hansen 1999) and can provide for brokering opportunities between actors (Burt 1992; Granovetter 1973). Interestingly, both strong and weak ties are necessary within a social structure as they facilitate access to different kinds of information (Haythornthwaite 2001; Tenkasi and Chesmore 2003).

Recently scholars have also been examining the concepts of social capital at an organization level. This larger organizational notion of social capital has been termed "communal social capital" and is defined as the "benefit that accrues to the collectivity as a result of the positive relations between different groups, organization units, or hierarchical levels." (Ibarra et al. 2005, p. 360). These studies primarily pertain to the influence of network structure on such factors as organizational performance, socialization, communication, knowledge transfer, innovation, and productivity (Song et al. 2007). Studies in the business literature have suggested that strong ties within and across units are associated with initiating and sustaining successful large-scale change efforts (McGrath and Krackhardt 2003; Tenkasi and Chesmore 2003). In fact, Cooper and Markus (1995) found that inattention to the strength of network ties during a significant organizational change effort of a large corporation resulted in a failed strategy.

Networks are typically identified by the content that is exchanged between actors or flows through the social ties (Scott 2000; Wasserman and Faust 1998). Any number of resources may move through both formal and informal social networks. For example, communication networks might encompass information exchange, knowledge transfer, and advice networks. The content of the network flows through relationships creating a structure that defines the purpose of the network and in turn how well the resources flow between actors (Wasserman and Faust 1998). For example, the social structure of a workrelated knowledge network may differ significantly from the structure of a more normative social network, such as friendship. In both examples resources flow through ties (the first 
being knowledge, the second friendship), but the overall structure of the network may look quite different. These network structures may facilitate the transfer of resources if the necessary relationships are in place and are accessible, but they may also constrain resource exchanges if the ties do not have sufficient connectivity to move the resource (Hite et al. 2005). In many cases, the underlying social structure determine the type, access, and flow of resources to actors in the network leading some scholars to suggest that the old adage 'It is not what you know, but who you know', is more accurately, 'Who you know defines what you know' (Cross et al. 2003).

In traditional social science research the attributes of the individual actor matter most. By contrast, in SNA, attributes, while important, take a secondary role to the ties with other actors in the network. SNA can reveal the underlying network structures that are important in understanding resource exchanges between individuals and groups within an organization (Cross et al. 2002; Song et al. 2007). Understanding these network structures may be useful for educational organizations enacting change as these underlying networks may be leveraged to better create, use, and diffuse knowledge and innovation (Cross et al. 2002). These resources may be of particular use as districts attempt to innovate and adapt to meet demands in high-stakes educational contexts.

Enhancing the strengths of ties between hierarchical levels within an organization is also critical to building an organization's capacity for change (Kogut and Zander 1996). Intraorganizational interaction and communication is important for the diffusion of new ideas and stable ties between sub-groups within an organization as they facilitate knowledge transfer, cooperative relationships, and innovation (Ghoshal et al. 1994; Song et al. 2007; Tsai and Ghoshal 1998). Informal networks within and between units that have dense ties generally achieve at a higher levels of performance than those with sparse connections (Reagans and Zuckerman 2001). This suggests that the overall structure of the network is important not only to individual resource advantage, but in achieving larger organizational goals (Guzzo and Shea 1992).

In addition to the benefits of dense connections between levels in an organization (including the administrative layers of a school district), units within the larger organization (such as schools) benefit from being connected to other similar units as a way to communicate information and gain novel knowledge (Tsai 2001). These lateral connections are critical for the development of complex information, knowledge exchange, and innovation. In addition, dense lateral ties increase a unit's 'absorptive capacity,' defined as a group's ability to assimilate and replicate new information from external sources (Cohen and Levinthal 1990). Absorptive capacity builds cumulatively with prior knowledge, meaning that the better equipped a unit is with prior related knowledge often predicts how well new information is absorbed into that unit. The ability of a sub-group to absorb information is directly related to the output of information from that group (Balkundi and Harrison 2006; Szulanski 1996). This input-output relationship creates a reciprocal process that is facilitated by ties within and between lateral units. Therefore, investing in a subgroup's ability to take in information from other sub-groups may lead to that unit outputting additional new information into the larger organization. This suggests the importance of dense lateral ties as a way to build absorptive capacity and support overall organizational goals (Tsai 2001). In an educational system this might be accomplished by creating clusters of site administrators who interact and share work-related knowledge.

The balance of scholarship in this section suggests that dense interconnected networks of communication and knowledge transfer at all levels of the system may maximize the uptake of complex knowledge thus increasing the potential for organizational change. Social network studies in the field of education have examined principal networks 
(Friedkin and Slater 1994); school and teacher networks (Bakkenes et al. 1999; Granovetter 1986; Penuel et al. 2007; Penuel et al. 2009); teacher professional development networks (Lima 2007); departmental structures (Lima 2003, 2004; Spillane 2006); schoolparent networks (Horvat et al. 2003); and between school networks (Mullen and Kochan 2000). In addition, two studies have examined the leadership network of an entire school district (see Hite et al. 2005, 2006). Building off of these previous studies, a careful exploration and analysis of the network of social relations may offer a nuanced understanding of facilitative and constrictive conditions for change in an INI district.

\section{Methods}

We used an exploratory case study design to examine the communication and knowledge networks among principals and central office staff in the Dos Mundos School District, using Social Network Analysis (Scott 2000; Wasserman and Faust 1998) and semistructured interviews (Patton 1990). A case study approach is most appropriate when the phenomenon of interest has a level of complexity that requires multiple data sources and methods to gain an in-depth understanding (Yin 2003). We selected Dos Mundos, as it is a mid-size school district that is both undergoing and poised to enact a significant change effort this school year through its strategic plan developed primarily in response to its INI status under NCLB. In addition, the district was selected as it reflects the diversity of student population found in many schools across California and in urban settings across the U.S. Dos Mundos serves students in kindergarten through eighth grade in eighteen schools, and is located in a rapidly growing 'urban fringe' area north of Los Angeles, California. The district has 16,000 students of whom $40 \%$ are Latino, $30 \%$ are African American, and $27 \%$ are White. Of the total student population $66 \%$ are classified as low socio-economic status and over $15 \%$ are English Language Learners. The district is in the third year of INI and facing greater sanctions from failure to meet Adequate Yearly Progress benchmarks under NCLB that may result in significant intervention.

\section{Data collection}

\section{Social network analysis}

In order to assess the social networks in Dos Mundos we developed an online survey that comprised 20 distinct networks and demographic questions. Network questions were generated from previous network research (Cross and Parker 2004) and original items. Specifically, we asked respondents to quantitatively assess their relationships with each of the other 58 administrators on a 5-point interaction scale ranging from 1 (no interaction) to 5 (1-2 times a week). For this paper we will narrow our findings and discussion to two of the key networks, communication and knowledge transfer as those have been repeatedly identified in the literature as associated with change efforts. For the communication network we asked every administrator to respond to the survey prompt, "Please rate every administrator in the Dos Mundos network as to whom you communicate with in regard to work related tasks... and at what frequency?" The knowledge network was taken from the prompt, "Please rate every administrator in the Dos Mundos network as to whom you go to for work related knowledge....and at what frequency?"

Our study involved only those in formal leadership positions in the district, including the Superintendent, Assistant Superintendents, Directors, Supervisors from the Central 
Office and Principals and Assistant Principals at the school sites. For this study, we focused only on the administrators, rather than teachers, in an effort to understand the schoolcentral office leadership networks. Our recent work has suggested that schools become more centralized and rigid after being placed under sanctions, and as a result of this response and the high degree of pressures placed on principals, these actors may be more likely to mediate knowledge and information flow between the school and district (Daly 2009; Finnigan and Stewart 2008). Future studies will extend the work to include teacher leaders and site-level curriculum experts to provide a more complete network picture, as these actors often are important in the uptake, spread, and depth of change (Lima 2007; Spillane 2006).

Twenty-three district office and thirty-five site administrators responded to the survey representing $98 \%$ of the total administrative population in Dos Mundos. A high level of participation of individuals within a network is critical to ensuring validity. Table 1 provides the overall demographic qualities of the sample. We used a bounded/saturated network approach (Lin 1999; Scott 2000) meaning that we included all the members of the Dos Mundos leadership team (site and central office administrators). We provided respondents with a list of all leadership team members and asked them to respond to each relationship and the frequency of that interaction. We used a bounded approach to network data collection as it provides for a more complete picture of the leadership network and potentially more valid results (Lin 1999; Scott 2000).

\section{Interviews}

While the SNA provides details regarding the structure of the network, our interview data offers insights into the nature of communication and knowledge transfer in the district. We conducted eight 45-min interviews with administrators in different formal and informal positions in the organization. We selected four site administrators and four central office leaders to represent the different formal positions in the network. We interviewed these actors using a semi-structured interview guide (Patton 1990; Spradley 1980). The interview guides were designed to better understand the administrators' perspectives of communication and knowledge exchange between and among the central office and site leaders. We asked participants to describe the patterns of communication and knowledge flow between and among the group of leaders and to provide examples of the types of exchanges that occurred. We also asked interviewees to describe and explain the overall structure of the

Table 1 Demographics of Dos Mundos’ Leadership network

\begin{tabular}{|c|c|c|c|c|c|c|}
\hline $\begin{array}{l}\text { Primary } \\
\text { work } \\
\text { location }\end{array}$ & Gender & Ethnicity & Age & $\begin{array}{l}\text { Years } \\
\text { as an } \\
\text { educator }\end{array}$ & $\begin{array}{l}\text { Years in } \\
\text { administration }\end{array}$ & $\begin{array}{l}\text { Years } \\
\text { in Dos } \\
\text { Mundos }\end{array}$ \\
\hline $40 \%$ District & $59 \%$ Female & $\begin{array}{c}14 \% \text { African- } \\
\text { American }\end{array}$ & $\begin{array}{r}10 \% 30-34 \\
\text { years old }\end{array}$ & $12 \% 5-9$ years & $\begin{array}{c}38 \%<4 \\
\text { years }\end{array}$ & $\begin{array}{c}17 \%<4 \\
\text { years }\end{array}$ \\
\hline \multirow[t]{5}{*}{$60 \%$ Site } & \multirow[t]{5}{*}{ 41\% Male } & $3 \%$ Asian & $5 \% 35-39$ & $22 \% 10-14$ & $22 \% 5-9$ & $17 \% 5-9$ \\
\hline & & 7\% Latino & $38 \% \quad 40-49$ & $13 \% 15-19$ & $10 \% \quad 10-14$ & $14 \% 10-14$ \\
\hline & & 74\% White & $38 \% 50-59$ & $13 \% 20-25$ & $19 \% \quad 15-19$ & $24 \% 15-19$ \\
\hline & & $2 \%$ Other & $9 \% 60+$ & $29 \% 25+$ & $6 \% 20-25$ & $14 \% 20-25$ \\
\hline & & & & & $5 \% 25+$ & $12 \% 25+$ \\
\hline
\end{tabular}

$N=58$ 
network from their perspectives. We ended the interviews by asking what they might suggest to improve the flow of communication and knowledge within and across the system.

We selected these actors from different formal positions in the district based their location in the informal structure determined by how central the actor was in both the communication and knowledge network networks. Centrality generally refers to how many ties an actor either initiates or receives in relation to the specific network being examined. We divided the centrality scores of both networks into quartiles and then randomly selected two central office and site leaders from the 1st (least central) and 4th (most central) quartile. This allowed us to select respondents who represented different formal (by position) and informal (by centrality) positions in the network securing a range of perspectives.

\section{Data analysis}

\section{Social network data analysis}

We conducted a series of network measures using the UCINET software (Borgatti et al. 2002) to better understand the structure of the network. Given the extensive literature on the importance of tie intensity in networks, the fact that respondents are more accurate at identifying ongoing patterns than determining occasional interactions (Carley and Krackhardt 1999), and that we were interested in stable structural patterns (Krackhardt 2001), we dichotomized the data to include only the most frequent communication and knowledge ties between actors. In order to be considered a frequent tie individuals would have communicated or shared knowledge once every two weeks to a couple of times a week (4 and 5 on the rating scale). In using frequency as a proxy for tie intensity we built on the work of Borgatti (2007) who outlined four distinct types of relationships studied in social network analysis: Proximities (e.g., similarities or distances), Relations (e.g., kinship or roles), Flows (e.g., the exchange of money or goods), and Interactions (e.g., talking with, helping). Borgatti argues the most appropriate measure of intensity of tie is specific to the type or relationships the tie represents. For example, the strength of proximity-based tie should reflect "how proximal" two nodes are, either representing very small distances or very high correlations between profiles. For interactional ties, the type of relationship we research in this study, strength of tie can be measured either by quantity (how frequently do you interact) or quality (how 'good' is the interaction). In this study we focus on the quantitative aspects of the interaction measured by frequency in order to provide more comparability across respondents, as the qualitative aspect of 'quality' is necessarily subjective. However, it should be noted that using frequency alone has limitations such as not acknowledging the role quality (measured through expressive relations) may play on communication and knowledge networks (Marsden and Campbell 1984).

We first ran a density measure to determine the percentage of frequent ties within the communication and knowledge network in total. The density of a network is the number of connections between actors divided by the number of total possible connections and can be thought of as how tightly knit a network is. A dense network, meaning one with a high percentage of ties, is thought to be able to move resources more quickly than a network with fewer ties (Scott 2000). We also block-partitioned the data into central office and site level administrators to compare the density of communication and knowledge flow between ties in each of these subgroups. 
Centrality measures were taken on each of the actors to determine the total amount of ties an actor initiates and receives in the communication and knowledge networks. Centrality has been thought of as an index of activity (Freeman 1979). Highly central actors in a network have increased access to resources and a high potential to create new linkages that may enhance social capital and build organizational capabilities (Stuart 1998; Tsai 2000). Those who are less central to the organization may be on the periphery and receive less information and often do not have the opportunities to gain from the resources and information held by those in more central positions. Moreover, these less central individuals are more likely to receive only the resources deemed necessary by those in a more centralized position (Burt 2000), thus potentially restricting their perspective of the overall organization. Centrality therefore can be considered a point of intersection in which the person in the center of the intersection is able to disproportionately and more quickly amass resources, thus allowing this central individual to influence the network by determining where the resources flow (Raider and Krackhardt 2001).

Given our interest in the relations between district and site administrators we conducted an External/Internal ratio analysis, often referred to as an E-I index, that indicates the extent to which the overall organization is characterized by interunit, as opposed to intraunit, strong ties (Krackhardt and Stern 1988). The scale ranges from -1 completely internal (intraunit) ties to +1 completely external (interunit). This network measure assesses the relationship between external and internal ties based on a specific actor attribute (in this case work location, meaning either central office or site) by comparing the numbers of ties within groups and between groups. A group (in this case central office administrators or site administrators) is considered externally focused if relationships are more uniformly dense over the entire network (interunit), or internally focused if there is a small dense core of relationships within a segment of the network (intraunit). High E-I indices (more externally focused) have been associated with large-scale successful organizational change (Krackhardt and Stern 1988; McGrath and Krackhardt 2003) and greater unit cooperation (Nelson 1989) while low E-I scores potentially limit how well an organization negotiates external pressures (McGrath and Krackhardt 2003).

Lastly, we conducted a core periphery $(\mathrm{CP})$ measure to better understand the structure of the entire network. A CP network structure is defined as one that has a dense cohesive central core of actors with a less connected periphery (Borgatti and Everett 1999; Wasserman and Faust 1998). The CP network structure essentially determines to which degree actors belong to one group (core) or another (periphery). The $\mathrm{CP}$ measure compares a given overall network to a theoretically perfect $\mathrm{CP}$ model (highly centralized) and reports the correlation between the actual and idealized centralized structure providing a measure of the centralization of a network. This network measure is useful as CP structures have been associated with how well certain types of knowledge are transferred (Cummings and Cross 2003). In addition to the aforementioned network measures we conducted interviews around the social networks of communication and knowledge with central office and site administrators in Dos Mundos to enable us to acquire a deeper understanding of the characteristics and structure of the networks in this district.

\section{Interview data analysis}

We used the interview results to explore the perceptions of administrators in different structural positions (more and less central) in the network. The eight interviews were audio-recorded and transcribed verbatim. The first cut of the interview data consisted of an inductive analysis that allowed important themes to emerge "out of the data rather than 
being imposed on them prior to data collection and analysis" (Patton 1990, p. 390). Interview data were analyzed using a constant comparative analysis method (Boeije 2002; Glaser and Strauss 1967), as well as checking and rechecking emerging themes (Miles and Huberman 1994). We grouped responses to the prompt and compared the different perspectives of district and site administrators, as well as those in the least and most central positions in the network. The themes that arose from this preliminary analysis were then re-examined, looking for patterns across district office and school sites and structural position as connected to the social network survey findings. This process of constant comparison "stimulates thought that leads to both descriptive and explanatory categories" (Lincoln and Guba 1985, p. 341). In order to ensure the trustworthiness of interpretations, member-checking procedures were carried out as emerging themes developed and were shared with participants (Miles and Huberman 1994).

\section{Findings}

After analyzing the data several major findings about the leadership network in Dos Mundos emerged: (1) sparse communication and knowledge ties exist between site and district office leaders; (2) the district office administrators are central in the underlying social network and rely on technical exchanges; (3) frequent within district office ties and infrequent school-school connections were evident; and (4) the overall structure of the Dos Mundos Leadership network is centralized. In the following section, we discuss these key findings based on our analysis of both network and interview data.

Sparse communication and knowledge ties between site and district office leaders

After dichotomizing the data to reflect frequency of interaction, we measured the density of the communication and knowledge networks. Fifty-eight administrators in the bounded network represent a potential of 3,306 ties across district and site administrators. We first examined the communication network in Dos Mundos in terms of the rating given by administrators regarding the frequency of communication with other administrators around work-related tasks. Based on their responses, we found that the district had an overall density of $22 \%$, meaning that $22 \%$ of all possible ties in the network $(n=3,306)$ occurred at a high frequency (ties that occur at least once every two weeks and as many as a couple of times a week). This suggests a pattern of low interaction (less than once a month if at all) between and among central office and site administrators in the remaining $78 \%$ of the possible work-related communication network ties.

Next we examined the density of the knowledge network in terms of the frequency that respondents rated going to other administrator in the district for work-related knowledge. This network had an overall density of $13 \%$ (out of 3,306 possible ties) indicating an even less dense network in comparison to communication. This suggests that $87 \%$ of the remaining work-related knowledge transfer ties occur, if at all, less than once a month. This level of knowledge exchange system-wide may limit the amount of shared knowledge in the organization and perhaps inhibit efforts at complex change.

The measure of degree for the communication network had a mean of 5.379 with a standard deviation of 4.563 and a range of $0-27$, indicating that out of a network of 58 administrators the average leader is connected to five other administrators representing only $8 \%$ of the administrative team. More importantly, the large standard deviation and range indicates a high degree of variability between actors. The majority of actors in the 
network have limited communication ties to other administrators that may make systemwide communication more difficult as the average administrator is communicating with less than $10 \%$ of the total leadership network.

The knowledge network had a comparatively lower mean score to the communication network of 4.069 and standard deviation of 3.617 with a range from 0 to $21^{\circ}$. This variability indicates that a majority of actors are not in the structural position to either offer or receive work-related knowledge. In both the communication and knowledge networks district administrators had higher degree scores in comparison to site administrators ranging from 13 to 21 suggesting that the district office is more central in the network. Figures 1 and 2 created with Netdraw (Borgatti et al. 2002), a network visualization tool, graphically display the communication and knowledge network structures with the lighter color nodes representing the central office administrators and darker color the site leaders. Nodes are sized according to overall centrality (with larger nodes having higher centrality scores) and connecting lines indicate a frequent tie between actors. The type of shape, either circle or square, refer to the core-periphery model that will be discussed later.

District office administrators are central in the network and rely on technical exchanges

As is shown in both Figs. 1 and 2 while the central office administrators have the highest degree of centrality, thus indicating disproportionately large organizational influence, their centrality does not necessarily constitute ready access to less central parts of the network, namely the school sites. In fact, the majority of district office communication and knowledge comes from other central office administrators, as indicated by the ties between lighter colored nodes. The figures above illustrate the relatively frequent ties between central office administrators in both the communication and knowledge networks and comparatively less frequent ties between site administrators. This high frequency

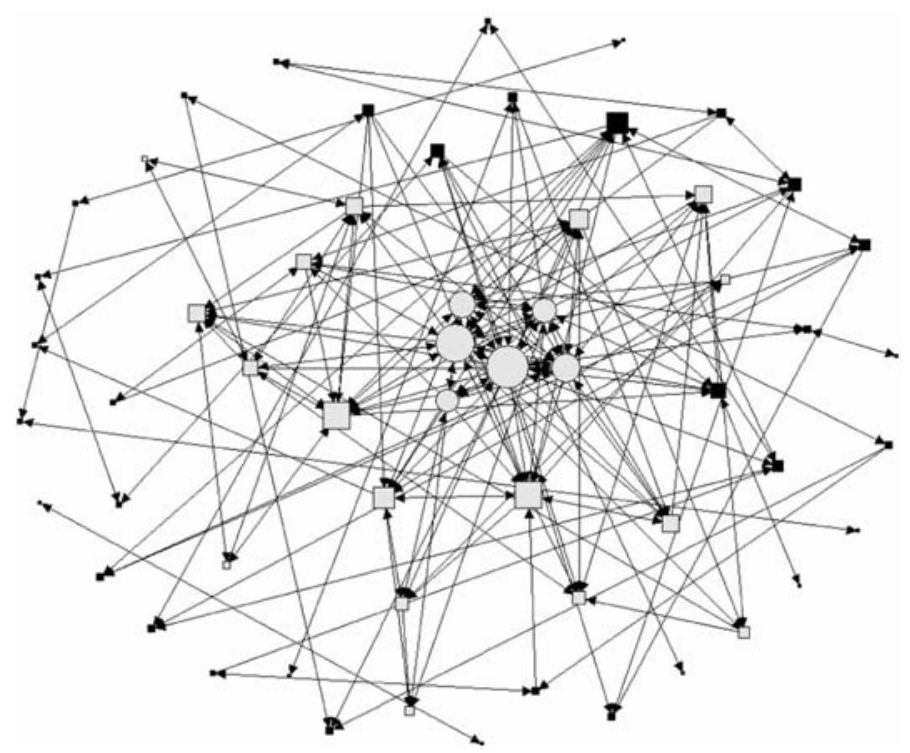

Fig. 1 Communication network (To whom do you communicate with in regard to work related tasks...and at what frequency?) 


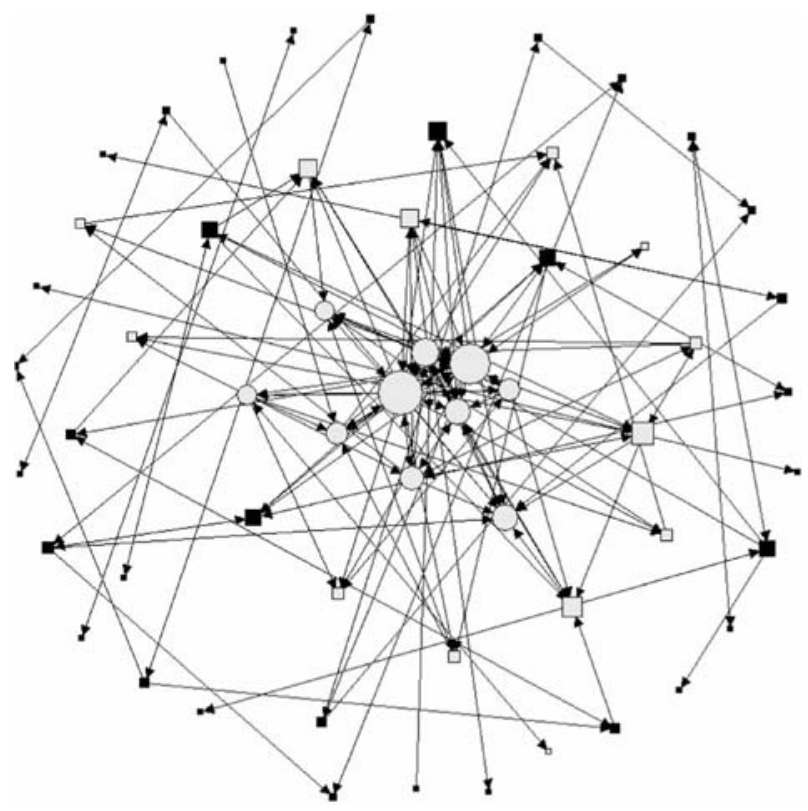

Fig. 2 Knowledge network (To whom do you go to for work related knowledge... and at what frequency?)

communication and knowledge sharing between central office leaders is useful in supporting consistency and coherence in terms of work-related activity, but it also may constrain opportunities for novel, non-redundant information to enter the central office. In addition, results suggest that the majority of site administrators are not central in either of the networks. Furthermore, they have limited high frequency work-related communication or knowledge ties with the central office or one another. With weak communication and knowledge ties of site administrators, this network structure may constrain the overall reform strategy in the district in terms of enacting a district-wide coherent change effort.

The school leaders described these communication patterns as one-way in nature, flowing to them from the central office. Furthermore, they reported that typically within communications is a request to produce some type of technical information to be reported to the district office. A more central principal of eight years in the network captured the general theme of centralized communication offering, "It is like we are cogs in the machine just responding to district mandates and not having the opportunity to share our views to the district office or each other $\left(\mathrm{P}^{2} \mathrm{M}^{2}\right)$."

Closely related to the centralized, technical communication patterns was the finding that site leaders perceived erosion in their ability to make decisions at the site. A less central principal stated,

Decision-making has become more autocratic with less of a shared decision-making process in place. This has forced me to give up some of my creativity and much of the control I once thought I had in terms of decisions and directions to take at the school. It now comes from the district office. (P1L).

2 The codes in parenthesis for all interview quotes refer to specific respondent attributes $(\mathrm{P}=$ principal, $\mathrm{D}=$ District; \# = Interviewee number; $\mathrm{H}=$ More Centrality; $\mathrm{L}=$ Less Centrality). 
While it was not clear whether this was a district response to the NCLB sanctions, our research in other districts suggests that this increased centralization and decreased sitebased authority may be closely linked to the 'threat' from accountability sanctions (Daly 2009). In combination, these themes suggest asymmetrical centralized communication patterns between the central office and site with district mandates and directives often overriding site leaders' ability to make school-level decisions. This finding was consistent regardless of the participants' centrality in the network.

Site administrators noted that communication and knowledge sharing tended to be more 'technical,' meaning that it was less about larger issues related to teaching and learning and more about budgets, prescriptive curriculums, and fidelity to district-adopted programs. In support of the idea, a more central principal shared,

The district office, who has been bottling level 5 leadership to us, are now only giving us more level 1, micro-management inflexible directives without culling them or without anything else and without a whole lot of direction or connection to our work at school (P3M).

Another less central principal offered, "The district belief is now that it is about the instructional materials you use, scripts allowed, time on task, and test scores, and less about developing relationships (P1L)." This more technically oriented, first-order communication pattern may constrain leaders from taking more adaptive (Heifetz and Linsky 2002), second-order approaches to change and will likely inhibit improvement.

The view of the factors affecting the underlying networks was somewhat different from the central office perspective with more of a focus on the lack of cohesiveness across the district. One less central assistant superintendent captured the overall feeling of central office administrators: "Part of our struggle with communication between the district and sites is that we're fragmented, broken into two worlds, and that has created challenges for us (D3L)." Another more central district office administrator concurred offering a similar frustration,

I am sitting with these people [site administrators] day after day, year after year, supporting them as many of the complaints that come out of the schools end up on my lap, and I try to resolve them, and I call them and share and communicate frequently, but I feel that we are not connecting. I just want to make it work (D4M).

Administrators in the district indicated that these challenges and minor frustrations might have to do with the nature of the work. Central office administrators see themselves as having a district-wide focus, while they perceive site administrators typically advocating only for their individual sites and often, “...missing the big picture, the overall plan that makes the district function as a whole (D4M)." Ironically, according to our findings it is likely difficult for site administrator to see the big picture as they are not as central in the larger network and have limited connections to district office leaders who have a broader perspective.

Frequent within district office ties and infrequent school-school connections

When we block partitioned the district office administrators from school site leaders an interesting network pattern emerged. In terms of the communication network, the central office administrators have a density of $30 \%$ frequent communication ties between one another compared with only $16 \%$ of the ties between site administrators. In addition $23 \%$ of the knowledge ties are frequent between central office administrators compared with $7 \%$ 
for site administrators. This data suggests a comparatively dense communication and knowledge network within the central office and sparse ties among site leaders with $93 \%$ of the site ties occurring less than once a month. This may significantly impede the ability of site administrators to communicate and share work-related knowledge that may inform practice; thus, potentially limiting the diffusion of innovation across schools within Dos Mundos.

In addition, the E-I index (ranging from -1 completely internal ties to +1 completely external) was run on the administrator's primary work location (central office or site). The overall E-I index for the communication network was $-.551 \quad(p<.01)$ and -.593 $(p<.01)$ for the knowledge network. These scores represent significantly 'internally' focused communication and knowledge networks. More internally focused networks indicate that there are stronger intraunit ties (i.e. among leaders in similar work locations) than interunit connections (i.e. between administrators at different work locations). This result suggests that there is limited network wide work-related communication or knowledge sharing that is critical across the system. While somewhat frequent communication and knowledge transfer occurs between central office leaders, this rarely occurs from central office to site administrators and between site administrators.

\section{Overall network structure is centralized}

The density, centrality, and E-I index taken on balance suggest a centralized network structure. In order to test the degree to which the structure forms a CP model, we conducted a continuous core/periphery analysis. This analysis provides a measure of the centralization of the network. Results for the communication network indicate a moderate .48 correlation with a perfect core-periphery model and a .43 correlation for the knowledge network. Both networks resulted in 10 actors comprising the core, all of whom were central office administrators, and the remainder of the actors, including all of site administrators, was on the periphery. In addition, expected values were calculated and a metric Multi-Dimensional Scaling (MDS) was run. MDS provides a visual representation of the pattern of proximities among a set of actors (Kruskal and Wish 1978). These coordinates were entered into Netdraw (Borgatti et al. 2002), and were plotted with work location and centrality scores and are included in Figs. 1 and 2. Again, the lighter color nodes represent the district office and darker color the site, while bigger sizes represent larger centrality scores. The circles refer to nodes in the 'core' and the squares to those in the 'periphery'. As is evident in the visualizations, both networks are centralized with the district office representing the core of the network and the sites on the periphery. Sparse ties, limited interunit interaction, and the centralized structure of Dos Mundos' communication and knowledge networks according to network theory may constrain the enactment of successful change strategies.

Triangulating this finding regarding limited interaction among principals, the principals voiced concerns around restricted opportunities for interaction, but there were subtle differences according to centrality. One principal with less centrality noted that she did not, "have as many colleagues to turn to as I would like" as it seemed "hard in the current climate to have time to reach out" (P4L). Interestingly, despite desiring more professional interaction, principals with low centrality seemed to share a sense of reticence from engaging with the larger system. As one said, "I just keep my head down and try to do my job (P1L)." Site leaders with more centrality seemed eager to have the chance to spend more time in professional dialogue, "I regularly talk with a couple of principals and we share our war stories as we can. We have collaboration time for teachers, but we as 
principals only interact at our infrequent meetings and they always have full agendas (P2M)." The site administrators, on balance, wanted more professional interaction, but underlying issues of reticence related to those administrators who are on the periphery of the network needs to be addressed.

Central office leaders pointed to the importance of the upcoming strategic plan as a way to move the district out of INI. The need and potential of the new plan was echoed by all of these leaders as a way to build, move, and strengthen the district. As a less central district office leader shared, "We need to build on our new strategic plan next year to increase communication so that we can raise student achievement through processes that improve a sense of togetherness, coherence, and less reliance on the district office (D2L)." The new change strategies put forth in the strategic plan include a significant amount of collaboration that appeared to have engendered a renewed sense of commitment to the work of the district and may in fact serve to build bridges between the two worlds of district office and site. A central office administrator with the highest degree of centrality in the Dos Mundos network shared, "With our new plan as a leader I am rededicating myself to being more conscious of fostering the communication process, and when you foster communication, you foster collaboration, and you foster trust that builds relationships and commitment (D1M)." Perhaps the commitment and energy of this extremely 'well connected' administrator will be able to engender a sense of possibility and renewal throughout the organization.

Our examination of the underlying networks in Dos Mundos indicate that relatively sparse communication and knowledge ties exist between and among site administrators and between central office and site leaders. On the other hand, the dense communication and knowledge ties that exist between central office administrators may lead to redundant communication and knowledge transfer, limiting the injection of novel information. Furthermore, centralized communication and technical knowledge transfer dominate the interactions between the central office and site. The overall social structure of both the communication and knowledge network has a centralized core of district office administrators with the majority of site leaders on the periphery. This structure may reflect limited system-wide interaction with administrators being focused more on within group communication and knowledge sharing. Perhaps the sparse communication and knowledge ties are due to an ingrained pattern of asymmetrical, technical exchanges that have become so prevalent and expected that they constrain the development of new ties. Although some leaders who were less central to the network indicated some reticence to engage the larger system, there appears to be an unrealized readiness to build more linkages among leaders and between organizational levels.

\section{Discussion and implications}

Through this exploratory study we have attempted to examine the district's capacity for change as the leaders of Dos Mundos implement new reforms in an effort to move out of INI status. In this section we discuss the findings, as well as the implications for policy and practice, limitations of our study, and directions for future research.

\section{Change and accountability in Dos Mundos}

In this paper we have drawn upon the broader literature of social capital and social network theory as a foundation to suggest that underlying social networks may enable an 
understanding of facilitative or constrictive conditions for change in districts in need of improvement (INI) under NCLB. As we have discussed, examining Dos Mundos' networks provides important insights into the current underlying relationships among district leaders and the ways in which these interactions may support or constrain change. We begin by discussing the key aspects of these relationships that may limit the type of organizational change that is required under NCLB. Next we discuss two key areas of literature-organizational inertia and organizational threat-that suggest changes to these networks will require focused attention to enable district staff to develop the types of networks that are required to support the transfer of communication and knowledge throughout the district.

Ties

Strong connections between administrators are important to a coordinated change strategy as these ties support the transfer of tacit, non-routine, and complex knowledge allowing for joint problem solving and the development of coordinated solutions (Hansen 1999; Reagans and McEvily 2003; Uzzi 1997). In effect, while the strategic plan may prescribe particular ways of responding, it is ultimately the social ties between individuals that will determine the shape, diffusion, and success of any change strategy. Therefore, attention to the creation of meaningful strategic ties that enhance information transfer between administrators may support the generation and diffusion of knowledge potentially increasing the social capital in the district, as well as exposing knowledge gaps that could be specifically targeted. Working against the development of these ties for knowledge exchange is the current centralized network structure of Dos Mundos.

Analysis of the informal social relations within the district revealed the presence of a core-periphery (CP) structure for both the communication and knowledge networks. These networks are characterized by a significant level of centralization around a few individuals with others inhabiting a more peripheral position. $\mathrm{CP}$ structures limit the contribution and access to valuable knowledge by marginalizing individuals at the periphery and ultimately having a negative impact on intra-organizational knowledge sharing (Tsai 2002). A highly centralized structure is effective for the diffusion of routine non-complex knowledge and information (Cummings and Cross 2003), such as technical material related to procedures and protocol as was discussed in the interviews. However, this type of structure has been found to impede the effectiveness of groups engaged in non-routine, complex tasks, such as high level communication (Borgatti and Cross 2003), knowledge sharing (Tsai 2002) and organizational change (Cummings and Cross 2003; Tenkasi and Chesmore 2003). In Dos Mundos, site administrators were typically on the periphery and somewhat disconnected from other principals and the 'core' of central office administrators. The isolation of principals from central office staff may stem from aspects of the organizational structure within districts that divides, rather than connects, central office staff and school administrators. Therefore, structures that support the development of more collaborative relationships between administrators should be considered.

Dos Mundos as a district-wide leadership team may be well served to create formal structures in the organization based on informal social networks to enhance existing ties and bolster those that are sparse (Cross et al. 2002). However, the district will have to avoid the trap of merely providing time and directives to 'work together' as this does necessarily result in meaningful collaboration between leaders. In fact, 'forced' collaboration may potentially calcify recalcitrant participants, making both present and future efforts at collaboration even more challenging (Harris and Chrispeels 2006). In fact, recent research by Coburn and Russell (2008) suggests that while districts may create specific 
roles (e.g. coaches) intended to increase collaboration the result is not always realized. Therefore, the development of structures must also include intentional opportunities for routines of interaction that promote productive exchange (Coburn and Russell 2008). Building and strengthening these relationships may enhance the district's capacity for change by further developing the social capital within the system (Lin 1999). Through new lateral connections, the organization's absorptive capacity for learning, development, and goal attainment will be strengthened (Cohen and Levinthal 1990).

\section{Inertia}

Our data suggests that the centralized communication and knowledge network structure of Dos Mundos may have been in place for a considerable number of years. Literature on network change suggests that intraunit and interunit networks tend to become stable over time. The inflexibility of these networks may exert influence on the ability to change social ties and accomplish organizational goals (Kim et al. 2006). This may account for the difficulty Dos Mundos has experienced in moving previous change strategies forward in an effort to exit INI. In addition, the more established and larger an organization is the less likely network ties will change - this can be thought of as the 'inertia' of the organization (Kim et al. 2006). The demographic data of the Dos Mundos administrators indicate that over $50 \%$ of administrators have been in Dos Mundos for 15 or more years. Perhaps this longevity supports a powerful organizational inertia.

In addition to inertia, district offices have to redefine their roles as they shift from monitoring to supporting low-performing schools in the current accountability policy context. As Honig (2006) points out, central office administrators' 'boundary spanning' activities enable local implementation at the school site by sharing information and resources, but are often short-lived because of other demands, as well as a lack of clear parameters about how to support schools in improvement. More explicit attention to the redefined roles of central office administrators and establishment of structures that support boundary spanning roles for both central office and site leaders may better connect administrators. However, the existence of networks alone is insufficient, as individuals within the district must possess the knowledge, skills, and high levels of trust among staff to facilitate these change processes (Spillane and Thompson 1998).

One method for 'unfreezing' the system in an effort to counter organizational inertia and build trust may be a formal facilitated process of reporting back network data to the district administrators. Social network maps can be shared without identifying information as a way to create awareness about network structure, communication patterns, and isolated actors. This facilitated analysis can support the system in creating new pathways and linkages throughout the organization thus loosening inflexible systems (Cross and Parker 2004; Cross et al. 2002; Kim et al. 2006). In addition, providing an opportunity to reflect on networks, engage in meaningful dialogue, and create actionable outcomes has the potential to open communication, develop trust, and build the capacity of the district to enact system-wide change.

\section{Threat}

In addition to the relationship between underlying networks and formal structures, external threats to the organization may contribute to systemic rigidity and centralization of communication. The threat-rigidity thesis postulates that when faced with significant threat, organizations may restrict information flow, engage in poor decision-making, and 
limit divergent views thereby essentially 'protecting' the organization from perceived attack (Staw et al. 1981). Mellahi et al. (2002) illustrate this case with examples from government and business showing that under a perceived threat organizations often create rigid hierarchical systems, centralize top-down decision-making, limit access to open communication, enact habituated/stereotyped responses, and stifle divergent views. The threat-rigidity thesis applied to the school setting in studies by Griffith (2004) and Rosenblatt (2004) generally supports this idea and also find a lack of flexibility in using existing knowledge. Ironically, in the short run, a threat-rigid response may help address the immediate threat, but ultimately may undermine the long-term capacity of individuals and organizations to negotiate stressful conditions and thrive (Daly 2009; Finnigan and Stewart 2008; Griffith 2004). Our data suggest that Dos Mundos has a number of characteristics associated with a threat-rigid response from a pervasive threat of sanction under NCLB. Perhaps organizations under threat from sanction may, in fact, calcify centralized network structures and become more internally focused both of which may undermine change strategies.

A network simulation study by Krackhardt and Stern (1988) supports this assertion suggesting that under threat networks tend to become more closed to outside influence. This internal focus may limit the way organizations negotiate external pressures (McGrath and Krackhardt 2003). In contrast, more externally focused networks have been associated with large-scale successful organizational change (Krackhardt and Stern 1988; McGrath and Krackhardt 2003) and greater unit cooperation (Nelson 1989). Dos Mundos' more internally focused communication and knowledge networks, as measured by the E-I index, may be indicative of an organization under threat and may ultimately constrain efforts at change.

Research suggests that the development of dense ties between units may moderate the networks response to threat (Krackhardt and Stern 1988; McGrath and Krackhardt 2003). In order for Dos Mundos to take advantage of the potential moderating effect of dense ties, the district may consider taking intentional action to create and sustain ties within and between central office and site leaders. This will require a shift in how Dos Mundos supports opportunities for interaction away from within unit ties (central office and site) to more cross unit ties (central office to site and vice versa). It is important to note that changes in fundamental existing ties may in the short-term result in disruption and suboptimal performance by the organization until the more functional ties are built and codified (Kim et al. 2006).

In essence, the current network structure in Dos Mundos will likely inhibit the type of complex system-wide collaborative change strategies this district must undertake to exit INI given the bulk of communication and knowledge sharing occurs primarily within the district office. In order to address the limiting features of the underlying networks that currently exist in Dos Mundos and increase the potential to move off INI, the district must work to include site administrators, who are the closest to where teaching and learning occurs and thus are able to diffuse successful practices across the district's schools. To do so, it will be important to maintain a strong core of communication within the central office that provides for rapid knowledge exchange and dissemination of technical information to sites, and create equally dense lateral ties between clusters of school site administrators serving similar student populations in order to generate new knowledge and be responsive to environmental change (Ghoshal et al. 1994; Tsai and Ghoshal 1998). These lateral connections are critical for the development of complex information and knowledge ties that build social capital as well as support the absorptive capacity of sites to assimilate and replicate new knowledge (Cohen and Levinthal 1990; Coleman 1990; Cummings and 
Cross 2003; Lin 2001; Tsai 2002). Inter and Intra-group sharing in Dos Mundos will enhance the overall district capacity for reform through increased social capital, collective learning, and synergy making successful large-scale change more likely (Smylie et al. 2003).

Implications for policy and practice

Policy

Over the last three years as a district in INI, Dos Mundos has engaged numerous reform efforts. These fragmented policies have not resulted in the desired outcomes and now the district is implementing a significant system-wide reform through its strategic plan. Similar to the other efforts at reform, this attempt will also be layered onto existing networks that may in fact constrain these efforts in taking hold (Tsai 2002). Simply providing for more communication and collaboration is not the answer in successful change policies (Cross et al. 2002), rather it is strategically and intentionally leveraging and moving the workrelated knowledge in the organization to meet goals. In the case of Dos Mundos, staff have invested heavily in strengthening the human capital of the administrators in terms of trainings, programs, and curricula. This reliance on focused training, narrow range of texts, prescriptive curricula, and standardized measurement systems has increasingly been the policy response INI districts and schools have adopted (Daly 2009; Center on Educational Policy 2006). Perhaps the increasing formal and structural linkages between federal, state, and district policy levers (Datnow et al. 2006) have foreground a more human capital, resource management approach to improvement, which in turn may have constrained the development of relational linkages between districts and sites thus limiting the ability to leverage existing social capital (Smylie and Evans 2006). The sparse ties evidenced in Dos Mundos may be an unintended consequence of these formal and structural policy linkages, and may inhibit significant progress toward exiting INI.

In addition to these policy linkages recent research suggests that under high-stakes accountability, school-central office relations become more bureaucratic and rule-bound (Daly 2009). However, effectively responding to state and federal accountability policies at the local level may require a more collaborative relationship among and between central office and school administrators to allow for the diffusion of innovation and knowledge. In essence, the historical patterns of principal isolation must be addressed, but are not currently the focus of more technically oriented policy levers. While some examples exist of principal-principal or superintendent-superintendent networks (Elmore 2004), strong school administrator-central office administrator networks are more rare and perhaps hold unrealized potential for change. Formally creating the opportunities and structures for these networks to flourish and generate social capital within Dos Mundos may support the implementation of both accountability and policy aimed at change (Smylie and Evans 2006). It bears noting that this emphasis on the more relational policy linkages suggests an equally important supplementing, not a supplanting, of the more technical aspects of school improvement that is currently demanded by federal and state policy instruments. It is the interaction of these two important elements that may yield the most positive outcomes.

\section{Practice}

Sparse ties may inhibit the transfer of best practices between schools and the district office, as those ties are not conducive to the transfer of more complex practices associated with 
change efforts (Cohen and Levinthal 1990; Reagans and Zuckerman 2001; Tsai 2001). Knowledge transfer related to what is currently working in the Dos Mundos School District may be critical in moving the district out of INI status. For example, one of the schools in Dos Mundos has successfully exited a state mandated improvement program, yet the strategies for their success have not been systematically diffused throughout the system. As network research suggests, if this tacit knowledge only resides in a peripheral corner of the network, then accessing and leveraging that knowledge to meet organizational goals may be difficult (Kilduff and Tsai 2003). The implications of this line of scholarship would suggest that prior to any additional investment in human capital, a system-wide effort in making tacit knowledge and practices explicit (or more formal attempts to engage in knowledge sharing) might be an effective strategy.

Network data provides insight into which individuals are in the best structural position (i.e., highly central actors) to move knowledge and practice throughout the system. Currently, while these are mostly individuals at central office, it will be important over time to intentionally create opportunities for site administrators to play more central roles in the diffusion of knowledge and practice, as they are often closest to effective instructional approaches. These well-connected individuals can serve as points of contact to lesserconnected actors perhaps building the social capital of the entire system and supporting efforts at reform, policy implementation, and knowledge exchange (Honig 2006). Strategically placed actors that hold highly central position in the network may also benifit collaboration and sustain efforts at reform. A more coordinated effort at building ties within groups of administrators and between different levels in the system is critical to enhancing an organization's overall capacity for change, increasing the likelihood of success (Kogut and Zander 1996; Smylie and Evans 2006) and perhaps removal from INI status.

\section{Delimiters and areas for future research}

There are several limitations to this exploratory case study. Although the case has provided insight into the social structure of a district in need of improvement, it is a case study of one district, which limits the generalizability of findings. We relied on frequency of interaction as indicators of intensity of relationship and did not include any additional networks that may have provided for a more accurate assessment of tie strength such as a quality measure. Measuring both the instrumental ties as we have done in this study combined with expressive ties would make for a stronger study (Burt 1997; Marsden and Campbell 1984). By focusing only on school administrators as opposed to other leaders in the organization, we may have under-represented the connections between schools and central office staff as other central office staff and school staff, such as reading or special education coordinators at the school site, may be in more frequent communication with each other compared with the administrators at the central office and school site included in our study. Lastly, we interviewed $15 \%$ of the total administrative network in Dos Mundos and despite randomly selecting individuals from a range of degrees of centrality the interviewees may not be representative of the larger sample. These delimiters of the study also point to additional areas for inquiry and analysis.

As this is one of the earliest exploratory case studies of an entire district's leadership network in an INI district additional research is clearly warranted. First, we are interested in further examining the social networks in Dos Mundos, including the networks of innovation and trust to examine whether the same highly centralized pattern exists. In addition, networks are dynamic (Kilduff and Tsai 2003) suggesting the importance of 
studying networks over time. These longitudinal studies may allow us to examine the interaction between network structures, implementation of change strategy, and resulting outcomes over time. Additional research could also look more closely at those districts that move off of INI status to examine whether these districts have stronger or more decentralized networks compared with those that continue to perform at low levels. Finally, examining network structures across INI districts may provide for insights into structural patterns that may have policy development implications. Although an important starting point, our study clearly indicates the need for additional research to better understand the underlying network structure of educators as they enact change strategies in response to NCLB.

\section{A bridge between worlds}

The research on social networks suggests that this type of analysis may provide critical information regarding the capacity to change, thereby introducing an intermediary step in the improvement process. Although leaders may perceive they have a good understanding of the social network of interactions around them based on their perceptions of relationships, research suggests that their perceptions are not very accurate and in fact the accuracy of their perceptions for some networks decline as one ascends the hierarchy (Casciaro 1998; Cross and Parker 2004; Kilduff and Krackhardt 1994). Scholarship on leadership and the use of social networks suggest that leaders need to attend to both their own cognitive views of the relationships, as well as carefully examine the existing patterns to best maximize organizational outcomes (Balkundi and Kilduff 2005). Social network theory and analysis may enable central office and site leaders to build and sustain bridges of communication, support, and knowledge between their worlds as they enact system-wide change.

Open Access This article is distributed under the terms of the Creative Commons Attribution Noncommercial License which permits any noncommercial use, distribution, and reproduction in any medium, provided the original author(s) and source are credited.

\section{References}

Agullard, K., \& Goughnour, D. S. (2006). Central office inquiry: Assessing organization, roles, and actions to support school improvement. San Francisco: WestEd.

Ahuja, G. (2000). Collaboration networks, structural holes, and innovation: A longitudinal study. Administrative Science Quarterly, 45(3), 425-455. doi:10.2307/2667105.

Bakkenes, I., De Brabander, C., \& Imants, J. (1999). Teacher isolation and communication network analysis in primary schools. Educational Administration Quarterly, 35, 166-202. doi:10.1177/00131619921 968518.

Balkundi, P., \& Harrison, D. (2006). Ties, leaders, and time in teams: Strong inferences about network structures effects on team viability and performance. Academy of Management Journal, 49(1), 49-68.

Balkundi, P., \& Kilduff, M. (2005). The ties that lead: A social network approach to leadership. The Leadership Quarterly, 16, 941-961. doi:10.1016/j.leaqua.2005.09.004.

Bartunek, J. (2001). Remarks on social networks in organizational change. Paper presented at the Academy of Management annual meeting, Washington, DC.

Berman, P., \& McLaughlin, M. W. (1978). Federal programs supporting educational change, Vol. VIII: Implementing and sustaining innovations. Santa Monica, CA: Rand Corporation.

Boeije, H. (2002). A purposeful approach to the constant comparative method in the analysis of qualitative interviews. Quality \& Quantity, 36, 391-409. doi:10.1023/A:1020909529486.

Borgatti, S. (2007). Typology of ties. Keynote speech presented at the international Sunbelt conference. St. Petersburg, Florida. 
Borgatti, S., \& Cross, R. (2003). A relational view of information seeking and learning in social networks. Management Science, 49(4), 432-445. doi:10.1287/mnsc.49.4.432.14428.

Borgatti, S., \& Everett, M. (1999). Models of core periphery structures. Social Networks, 21, 375-395. doi: 10.1016/S0378-8733(99)00019-2.

Borgatti, S., Everett, M., \& Freeman, L. (2002). UCINET for Windows: Software for social network analysis. Harvard, MA: Analytic Technologies.

Borgatti, S., \& Foster, P. (2003). The network paradigm in organizational research: A review and typology. Journal of Management, 29(6), 991-1013.

Bourdieu, P. (1986). The forms of social capital. In J. G. Richardson (Ed.), Handbook of theory and research for the sociology of education (pp. 241-258). New York: Greenwood.

Brazer, S. D., \& Keller, L. R. (2008). A design research approach to investigating educational decision making. In A. E. Kelly, R. A. Lesh \& J. Y. Baek (Eds.), Handbook of design research methods in science, technology, engineering, and mathematics learning and teaching (pp. 284-296). New York: Routledge, Taylor, and Francis.

Burch, P., \& Spillane, J. (2004). Leading from the middle: Mid-level district staff and instructional improvement. Chicago: Cross City Campaign for Urban School Reform.

Burt, R. S. (1992). Structural holes: The structure of competition. Cambridge, MA: Harvard University Press.

Burt, R. S. (1997). A note on social capital and network content. Social Networks, 19(4), 355-373. doi: 10.1016/S0378-8733(97)00003-8.

Burt, R. S. (2000). The network structure of social capital. In R. I. Sutton \& B. M. Staw (Eds.), Research in organizational behavior (pp. 1-83). Greenwich, CT: JAI Press.

Carley, K., \& Krackhardt, D. (1999). Cognitive inconsistencies and non-symmetric friendship. Social Networks, 18(1), 1-27. doi:10.1016/0378-8733(95)00252-9.

Casciaro, T. (1998). Seeing things clearly: Social structure, personality, and accuracy in social network perception. Social Networks, 20(4), 331-351. doi:10.1016/S0378-8733(98)00008-2.

Center on Education Policy. (2007). What now? Lessons from Michigan about restructuring schools and next steps under NCLB. Author: Washington, DC.

Center on Education Policy. (2008). Managing more than a thousand remodeling projects: School restructuring in California. Author: Washington, DC.

Center on Educational Policy. (2006). From the capital to the classroom. Author: Washington, DC.

Chrispeels, J. (2004). Learning to lead together: The promise and challenge of sharing leadership. Thousand Oaks: Sage Publications.

Coburn, C. E. (2005). The role of nonsystem actors in the relationship between policy and practice: The case of reading instruction in California. Educational Evaluation and Policy Analysis, 27(1), 23-52. doi: $10.3102 / 01623737027001023$.

Coburn, C. E., \& Russell, J. L. (2008). District policy and teachers' social networks. Educational Evaluation and Policy Analysis, 30(3), 203-235. doi:10.3102/0162373708321829.

Cohen, W., \& Levinthal, D. (1990). Absorptive capacity: A new perspective on learning and innovation. Administrative Science Quarterly, 35, 128-152. doi:10.2307/2393553.

Coleman, J. S. (1988). Social capital in the creation of human capital. American Journal of Sociology, 94, 95-120. doi:10.1086/228943.

Coleman, J. S. (1990). Foundations of social theory. Harvard University Press: Cambridge, MA.

Cooper, R., \& Markus, L. M. (1995). Human reengineering. Sloan Management Review, 36, 39-50.

Cross, R., Baker, W., \& Parker, A. (2003). What creates energy in organizations? Sloan Management Review, 44(4), 51-57.

Cross, R., Borgatti, S., \& Parker, A. (2002a). Making invisible work visible: Using social network analysis to support strategic collaboration. California Management Review, 44(2), 25-46.

Cross, R., Nohria, N., \& Parker, A. (2002b). Six myths of networks and how to avoid them. MIT Sloan Management Review, 43(3), 67-76.

Cross, R., \& Parker, A. (2004). The hidden power of social networks: Understanding how work really gets done in organizations. Cambridge, MA: Harvard Business School Press.

Cummings, J., \& Cross, R. (2003). Structural properties of work groups and their consequences for performance. Social Networks, 25, 197-210. doi:10.1016/S0378-8733(02)00049-7.

Daly, A. J. (2009). Threat rigid response in an age of accountability. Educational Administration Quarterly.

Datnow, A., \& Castellano, M. (2003). Leadership and success for all. In J. Murphy \& A. Datnow (Eds.), Leadership for school reform: Lessons from comprehensive school reform designs (pp. 187-208). Thousand Oaks, CA: Corwin Press.

Datnow, A., Lasky, S., Stringfield, S., \& Teddlie, C. (2006). Systemic integration for effective reform in racially and linguistically diverse contexts. Cambridge: Cambridge University Press. 
Dika, S. L., \& Singh, K. (2002). Applications of social capital in educational literature: A critical synthesis. Review of Educational Research, 72, 31-60. doi:10.3102/00346543072001031.

Dyk, P. H., \& Wilson, S. M. (1999). Family-based social capital considerations as predictors of attainments among Appalachian youth. Sociological Inquiry, 69(3), 477-503. doi:10.1111/j.1475-682X.1999. tb00882.x.

Earl, L., \& Katz, S. (2007). Leadership in networked learning communities: Defining the terrain. School Leadership \& Management, 27(3), 239-258. doi:10.1080/13632430701379503.

Earl, L., Katz, S., Elgie, S., Ben-Jaafar, S., \& Foster, L. (2006). How networked learning communities work. Toronto: Aporia Consulting Ltd. Downloaded on November 2006 from http://networkedlearning. ncsl.org.uk/collections/network-research-series/reports/how-networked-learning-communities-work.pdf.

Elmore, R. F. (2004). School reform from the inside out: Policy, practice, and performance. Cambridge: Harvard Education Press.

Elmore, R. F., \& Burney, D. (1997). Investing in teacher learning: Staff development and instructional improvement in Community School District \#2, New York City. New York: National Commission on Teaching and America's Future and the Consortium for Policy Research in Education.

Fielding, M. (2001). Taking education seriously: Four years hard labour. London: Routledge Falmer.

Finnigan, K., \& Stewart, T. (2008, March). Principal leadership in low-performing schools. Paper presented at the annual meeting of the American Educational Research Association.

Freeman, L. C. (1979). Centrality in social networks: Conceptual clarification. Social Networks, 1, 215-239. doi:10.1016/0378-8733(78)90021-7.

Friedkin, N., \& Slater, M. (1994). School leadership and performance: A social network approach. Sociology of Education, 67, 139-157. doi:10.2307/2112701.

Fullan, M. (2005). Leadership \& sustainability: System thinkers in action. Thousand Oaks: Corwin Press.

Ghoshal, S., Korine, H., \& Szulanski, G. (1994). Interunit communication in multinational corporations. Management Science, 40(1), 96-110.

Giddens, A. (1979). Central problems in social theory. Berkeley: University of California Press.

Glaser, B., \& Strauss, A. (1967). The discovery of grounded theory. New York, NY: Aldine De Gruyter.

Granovetter, M. S. (1973). The strength of weak ties. American Journal of Sociology, 78, 1360-1380. doi: $10.1086 / 225469$.

Granovetter, M. S. (1982). The strength of weak ties: A network theory revisited. In P. V. Marsden \& N. Lin (Eds.), Social structure and network analysis (pp. 105-130). Beverly Hills: Sage.

Granovetter, M. (1986). The micro-structure of school desegregation. In J. Prager, D. Longshore, \& M. Seeman (Eds.), School desegregation research: New directions in situational analysis. New York: Plenum Press.

Griffith, J. (2004). Ineffective schools as organizational reactions to stress. Social Psychology of Education, 7, 257-287. doi:10.1023/B:SPOE.0000037505.03707.fd.

Guzzo, R. A., \& Shea, G. P. (1992). Group performance and intergroup relations. In M. D. Dunnette \& L. M. Hough (Eds.), Handbook of industrial and organizational psychology (2nd ed., Vol. 3, pp. 269-314). Palo Alto, CA: Consulting Psychologist Press.

Hansen, M. T. (1999). The search-transfer problem: The role of weak ties in sharing knowledge across organization subunits. Administrative Science Quarterly, 44(1), 82-111. doi:10.2307/2667032.

Hargreaves, A., \& Fink, D. (2006). Sustainable leadership. Jossey-Bass: San Francisco.

Harris, A., \& Chrispeels, J. H. (Eds.). (2006). Improving schools and educational systems: International perspectives. London: Routledge.

Haythornthwaite, C. (2001). Tie strength and the impact of new media. In Proceedings of the 34th annual Hawaii international conference on systems sciences, Maui, Hawaii.

Heifetz, R., \& Linsky, M. (2002). Leadership on the line: Staying alive through the dangers of leading. Cambridge, MA: Harvard University Press.

Hightower, A. M., Knapp, M. S., Marsh, J. A., \& McLaughlin, M. W. (Eds.). (2002). School districts and instructional renewal. New York, NY: Teachers College Press.

Hite, J., Williams, E., \& Baugh, S. (2005). Multiple networks of public school administrators: An analysis of network content and structure. International Journal of Leadership in Education, 8(2), 91-122. doi: 10.1080/1360312042000329086.

Hite, J., Williams, E., Hilton, S., \& Baugh, S. (2006). The role of administrator characteristics on perceptions of innovativeness among public school administrators. Education and Urban Society, 38(2), 160-187. doi:10.1177/0013124505284289.

Honig, M. (2004). Crafting coherence: How schools strategically manage multiple, external demands. Educational Researcher, 33(8), 16-30. doi:10.3102/0013189X033008016. 
Honig, M. (2006). Street-level bureaucracy revisited: Frontline district central-office administrators as boundary spanners in education policy implementation. Educational Evaluation and Policy Analysis, 28(4), 357-383. doi:10.3102/01623737028004357.

Horvat, E., Weininger, E., \& Laureau, A. (2003). From social ties to social capital: Class differences in the relations between schools and parents network. American Educational Research Journal, 40(2), 319351. doi:10.3102/00028312040002319.

Hubbard, L., Mehan, H., \& Stein, M. (2006). Reform as learning. New York, NY: Routledge.

Ibarra, H., Kilduff, M., \& Tsai, W. (2005). Zooming in and out: Connecting individuals and collectivities at the frontiers of organizational network research. Organization Science, 16(4), 359-371. doi:10.1287/ orsc. 1050.0129 .

Kilduff, M., \& Krackhardt, D. (1994). Bringing the individual back in: A structural analysis of the internal market for reputation in organizations. Academy of Management Journal, 37, 87-108.

Kilduff, M., \& Tsai, W. (2003). Social networks and organizations. London, UK: Sage Publications.

Kim, T., Oh, H., \& Swaminathan, A. (2006). Framing interorganizational network change: A network inertia perspective. Academy of Management Review, 31(3), 704-720.

Kogut, B., \& Zander, U. (1996). What firms do? Coordination, identity, and learning. Organization Science, $7(5), 502-518$.

Krackhardt, D. (2001). Network conditions of organizational change. Paper presented at the Academy of Management annual meeting, Washington, DC.

Krackhardt, D., \& Stern, R. (1988). Informal networks and organizational crises: An experimental simulation. Social Psychology Quarterly, 51(2), 123-140. doi:10.2307/2786835.

Kruskal, J. B., \& Wish, M. (1978). Multidimensional scaling. Thousand Oaks, CA: Sage Publications.

Lasky, S. (2004). A Policy Framework for analyzing educational system effects, CRESPAR Technical Report 71. Baltimore, MD: Center for Research on the Education of Students Placed At Risk, Johns Hopkins University.

Leithwood, K., Louis, K. S., Anderson, S., \& Wahlstrom, K. (2004). How leadership influences student learning. Minneapolis: University of Minnesota, Center for Applied Research and Educational Improvement.

Leithwood, K., Mascall, B., Strauss, T., Sacks, R., Memon, N., \& Yashkina, A. (2007). Distributing leadership to make schools smarter: Taking the ego out of the system. Leadership and Policy in Schools, 6(1), 37-67. doi:10.1080/15700760601091267. Electronic version.

Levin, B. (2007). Sustainable, large-scale education reform. Journal of Educational Change, 8(4), 323-336. doi:10.1007/s10833-007-9041-y.

Lima, J. A. (2003). Trained for isolation: The impact of departmental cultures on student teachers' views and practices of collaboration. Journal of Education for Teaching, 29(3), 197-218. doi:10.1080/026 0747032000120105.

Lima, J. A. (2004). Social networks in teaching. In F. Hernandez \& I. F. Goodson (Eds.), Social geographies of educational change (pp. 29-46). The Netherlands: Kluwer Academic.

Lima, J. A. (2007). Teachers' professional development in departmentalized, loosely coupled organizations: Lessons for school improvement from a case study of two curriculum departments. School Effectiveness and School Improvement, 18(3), 273-301. doi:10.1080/09243450701434156.

Lin, N. (1999). Building a network theory of social capital. Connections, 22(1), 28-51.

Lin, N. (2001). Social capital: A theory of social structure and action. New York: Cambridge University Press.

Lincoln, Y., \& Guba, E. (1985). Naturalistic inquiry. Thousand Oaks, CA: Sage Publications.

Marsden, P. V., \& Campbell, K. E. (1984). Measuring tie-strength. Social Forces, 63, 482-501. doi: $10.2307 / 2579058$.

Marsh, J. A. (2002). How districts relate to states, schools, and communities: A review of emerging literature. In A. M. Hightower (Ed.), School districts and instructional renewal (pp. 25-39). Amsterdam, NY: Teachers College Press.

Marsh, J. A., Kerr, K. A., Ikemoto, G. S., Darilek, H., Suttorp, M., Zimmer, R. W., et al. (2005). The role of the district in fostering instructional improvement: Lessons from three urban districts partnered with the Institute for Learning. Santa Monica, CA: RAND Corporation.

Massell, D. (2000). The district role in building capacity: Four strategies. Philadelphia: Consortium for Policy Research in Education, University of Pennsylvania, CPRE Policy Brief No. RB-32.

Massell, D., \& Goertz, M. (1999). Local strategies for building capacity: The district role in supporting instructional reform. Paper presented at the annual meeting of the American Educational Research Association, Montreal, Canada.

McGrath, C., \& Krackhardt, D. (2003). Network conditions for organizational change. The Journal of Applied Behavioral Science, 39(3), 324-336. doi:10.1177/0021886303258267. 
McLaughlin, M. W. (1990). The Rand change agent study revisited: Macro perspectives and micro realities. Educational Researcher, 19(9), 11-16.

McLaughlin, M. W., \& Talbert, J. W. (1993). Contexts that matter for teaching and learning. Palo Alto, CA: Context Center on Secondary School Teaching.

McLaughlin, M. W., \& Talbert, J. (2003). Reforming districts: How districts support school reform. Seattle, Washington: University of Washington.

Mellahi, P., Jackson, P., \& Sparks, L. (2002). An exploratory study into failure in successful organizations: The case of Marks and Spencer. British Journal of Management, 13, 15-29. doi:10.1111/ $1467-8551.00220$.

Miles, M. B., \& Huberman, M. A. (1994). Qualitative data analysis (2nd ed.). Thousand Oaks, CA: Sage Publications.

Mintrop, H. (2004). Schools on probation: How accountability works (and doesn't work). New York: Teachers College Press.

Mintrop, H., \& Trujillo, T. (2005). Corrective action in low-performing schools: Lessons for NCLB implementation from first-generation accountability systems. Education Policy Analysis Archives, 13(48), 1-27. Retrieved June 29, 2007, from http://epaa.asu.edu/epaa/v13n48/.

Mohrman, S., Tenkasi, R., \& Mohrman, A. (2003). The role of networks in fundamental organizational change. The Journal of Applied Behavioral Science, 39(3), 301-323. doi:10.1177/0021886303258072.

Mullen, C., \& Kochan, F. (2000). Creating a collaborative leadership network: An organic view of change. International Journal of Leadership in Education, 3(3), 183-200. doi:10.1080/13603120050083891.

Nelson, R. (1989). The strength of strong ties: Social networks and intergroup conflict in organizations. Academy of Management Journal, 32(2), 377-401. doi:10.2307/256367.

Newmann, F., \& Wehlage, G. (1995). Successful school restructuring. Madison: Center on Organization and Restructuring of Schools, University of Wisconsin-Madison.

Orfield, G., Kim, J., Sunderman, G., \& Greer, B. (2004). No Child Left Behind: A federal, state, and district level look at the first year. Civil Rights Project, Harvard University.

Patton, M. Q. (1990). Qualitative evaluation and research methods (2nd ed.). Newbury Park, CA: Sage Publications.

Penuel, W. R., Frank, K. A., \& Krause, A. E. (2007, April). A social network approach to examining the effects of distributed leadership in schoolwide reform initiatives. Paper presented at the annual meeting of the American Educational Research Association, Chicago, IL.

Penuel, W. R., Riel, M. R., Krause, A., \& Frank, K. A. (2009) Analyzing teachers' professional interactions in a school as social capital: A social network approach. Teachers College Record, 111(1), 124-163.

Portes, A. (2000). The two meanings of social capital. Sociological Forum, 15(1), 1-12. doi:10.1023/ A: 1007537902813 .

Portes, A., \& Sensenbrenner, J. (1993). Embeddedness and immigration: Notes on the social determinants of economic action. American Journal of Sociology, 98, 1320-1350. doi:10.1086/230191.

Putnam, R. D. (1993). Making democracy work. Princeton, NJ: Princeton University Press.

Putnam, R. D. (1995). Bowling alone: America's declining social capital. Journal of Democracy, 6, 65-78. doi:10.1353/jod.1995.0002.

Raider, H., \& Krackhardt, D. (2001). Intraorganizational networks. In Joel A. C. Baum (Ed.), Companion to organizations (pp. 58-74). Oxford, UK: Blackwell.

Reagans, R., \& McEvily, B. (2003). Network structure and knowledge transfer: The effects of cohesion and range. Administrative Science Quarterly, 48(2), 240-267. doi:10.2307/3556658.

Reagans, R., \& Zuckerman, E. (2001). Networks, diversity, and productivity: The social capital of R\&D teams. Organization Science, 12, 502-517. doi:10.1287/orsc.12.4.502.10637.

Rosenblatt, Z. (2004). Skill flexibility and school change: A multi-national study. Journal of Educational Change, 5, 1-30. doi:10.1023/B:JEDU.0000022841.54071.36.

Rosenholtz, S. J. (1991). Teachers' workplace: The social organization of schools. New York, NY: Teachers College Press.

Scott, J. (2000). Social network analysis (2nd ed.). London: Sage Publications.

Smylie, M., Wenzel, S., \& Fendt, C. (2003). The chicago annenberg challenge: Lessons on leadership for school development. In J. Murphy \& A. Datnow (Eds.), Leadership lessons from comprehensive school reforms (pp. 135-158). Thousand Oaks: Sage Publications.

Smylie, M. A., \& Evans, A. E. (2006). Social capital and the problem of implementation. In M. I. Honig (Ed.), New directions in education policy: Confronting complexity (pp. 187-208). Albany: State University of New York Press.

Song, S., Nerur, S., \& Teng, J. (2007). An exploratory study on the roles of network structure and knowledge processing orientation in the work unit knowledge management. Advances in Information Systems, $38(2), 8-26$. 
Spillane, J. (2000). Cognition and policy implementation: District policy-makers and the reform of mathematics education. Cognition and Instruction, 18, 141-179. doi:10.1207/S1532690XCI1802_01.

Spillane, J. P. (1996). School districts matter: Local educational authorities and state instructional policy. Educational Policy, 1(1), 63-87. doi:10.1177/0895904896010001004.

Spillane, J. P. (2006). Distributed leadership. San Francisco: Jossey-Bass.

Spillane, J. P., \& Thompson, C. L. (1998). Looking at local districts' capacity for ambitious reform. Philadelphia: Consortium for Policy Research in Education, University of Pennsylvania.

Spradley, J. P. (1980). Participant observation. New York: Holt, Rinehart \& Winston.

Stanton-Salazar, R. D., \& Dornbusch, S. M. (1995). Social capital and the reproduction of inequality: Information networks among Mexican-origin high school students. Sociology of Education, 68, 116-135. doi: $10.2307 / 2112778$.

Staw, B. M., Sandelands, L. E., \& Dutton, J. E. (1981). Threat-rigidity effects in organizational behavior: A multilevel analysis. Administrative Science Quarterly, 26, 501-524. doi:10.2307/2392337.

Stevenson, W., Bartunek, J., \& Borgatti, S. (2003). Front and backstage processes of an organizational restructuring effort. The Journal of Applied Behavioral Science, 39(3), 243-258. doi:10.1177/0021 886303258073 .

Stuart, T. E. (1998). Network positions and propensities to collaborate: An investigation of strategic alliance formation in a high-technology industry. Strategic Management Journal, 43, 668-698.

Stullich, S., Eisner, E., McCrary, J., \& Roney, C. (2006). National assessment of Title I: Interim report, Vol. I: Implementation of Title I. Washington, DC: Institute of Education Sciences, National Center for Education Evaluation and Regional Assistance, U.S. Department of Education.

Sunderman, G. L., Kim, J. S., \& Orfield, G. (2005). NCLB meets school realities: Lessons from the field. Thousand Oaks, CA: Corwin Press.

Szulanski, G. (1996). Exploring stickiness: Impediments to the transfer of best practice within the firm. Strategic Management Journal, 17, 27-43.

Tenkasi, R., \& Chesmore, M. (2003). Social networks and planned organizational change. The Journal of Applied Behavioral Science, 39(3), 281-300. doi:10.1177/0021886303258338.

Togneri, W., \& Anderson, S. E. (2003). Beyond islands of excellence: What districts can do to improve instruction and achievement in all schools. Washington, DC: The Learning First Alliance and the Association for Supervision and Curriculum Development.

Tsai, W. (2000). Social capital strategic relatedness and the formation of intraorganizational linkages. Strategic Management Journal, 21, 925-939. doi:10.1002/1097-0266(200009)21:9<925::AID-SMJ $129>3.0 . \mathrm{CO} ; 2-\mathrm{I}$.

Tsai, W. (2001). Knowledge transfer in intraorganizational networks: Effects of network position and absorptive capacity on business unit innovation and performance. Academy of Management Journal, 44(5), 996-1004. doi:10.2307/3069443.

Tsai, W. (2002). Social structure of "coopetition" within a multi-unit organization: Coordination, competition, and intraorganizational knowledge sharing. Organization Science, 13(2), 179-190. doi:10.1287/ orsc.13.2.179.536.

Tsai, W., \& Ghoshal, S. (1998). Social capital and value creation: The role of intrafirm networks. Academy of Management Journal, 41(4), 464-476. doi:10.2307/257085.

Uzzi, B. (1997). Social structure and competition in interfirm networks: The paradox of embeddedness. Administrative Science Quarterly, 42(1), 35-67. doi:10.2307/2393808.

Wasserman, S., \& Faust, K. (1998). Social network analysis: Methods and applications. New York: Cambridge University Press.

Yin, R. K. (2003). Case study research, design and methods (3rd ed.). Newbury Park: Sage Publications. 